\title{
The Ethnic Identity Crisis and Acculturation in Shakir's "Let's Dance"
}

\author{
Hassan Ali Abdullah Al-Momani \\ English Department, Tafila Technical University, Jordan \\ E-mail: aasalkb@hotmail.com
}

Received: 04-10-2016

Published: 01-05-2017
Accepted: 06-01-2017

doi:10.7575/aiac.ijalel.v.6n.3p.88
Advance Access Published: March 2017

URL: http://dx.doi.org/10.7575/aiac.ijalel.v.6n.3p.88

\begin{abstract}
This study aims at investigating the ethnic identity crisis and the problems of acculturation and enculturation in Evelyn Shakir's "Let's dance." The study will present a close reading analysis of Shakir's story highlighting the problem of constructing the ethnic identity for the protagonist Nadia who suffers from the lack of her parental support and divorce. Additionally, the study presents the problems that most Arab American young adults suffer from when living in America such as the confusion of belonging to the Arab and American culture, the American negative media stereotypes about Arabs, and the conflict between Arab and American ethnic and cultural traditions. The study concludes that the parental problems and conflicts negatively influence the construction of Arab American young adults' ethnic identity and acculturation.
\end{abstract}

Keywords: ethnic identity, acculturation, enculturation, stereotypes, cultural identity, family support, ethnic identity crisis, ethnicity

\section{Introduction}

Britto and Amer explore highlight the influence of family support in Arab American young adults' acculturation and assimilation in American society. The researchers find that some Arab American young adults are stressed by their families who pressured them to be acculturative to their Arab culture and to be adhered to their Arab cultural identity and to the Islamic faith (137). The two researchers present a distinction between "cultural identity" term and "ethnic identity," in which cultural identity is defined as "multidimensional construct referring to a developing sense of self as a member of one or more groups" (138), whereas ethnic identity is "the affiliation with a specific group that shares a common ancestry, history, and traditions" (138).

The researchers note that the formation of identity starts from "a diffused notion" to "a more understanding of self" (138), and such process may vary from one person to another. They claim that there is a strong relationship between the construction of ethnic and cultural identities and family relations (138): "When the two cultures, the family and society, are at odds, developing a sense of cultural identity is challenging" $(138,139)$. Both researchers emphasize the role of family in their children's acculturation to the host culture (139).

Semaan studies the negative influence of American media stereotypes on Arabs on Arab American ethnic identity and acculturation after 9/11. The researcher finds out that such stereotypes negatively influenced Arab Americans who were discriminated by Americans based on their ethnicity and religious beliefs (28). Similarly, Awad explores two aspects of acculturation for Arab Americans which are "ethnic society immersion and dominant society immersion" (59). The researcher finds out that Arab Americans who were discriminated by the American society showed a lower level of acculturation to the American society, whereas those Arab American Christians who faced less discrimination showed that a high level of acculturation to the American culture (59). Weaver questions whether American society wants Arab Americans to be assimilated to their culture. She defines assimilation as "going from being and "other" to being 'one of us"'(100). The researcher concludes that "societal acceptance as the main barrier to Arab-American assimilation" (100).

In a very valuable study conducted by Hakim-Larson and Menna entitled "Acculturation and Enculturation: Ethnic Identity Socialization Processes," the researchers provide a distinction between the term "acculturation" which "involves the variety of different ways that a person can adapt to a culture that is different from that of their family's culture(s) of origin" (34), and "enculturation" which "involves learning about one's culture of origin" (34). The researchers describe the process of Arab Americans' enculturation to Arab culture which starts with "ethnic identity socialization, a process that is most likely to take place within the extended family life and local communities of Arab Americans" (34). According to Hakim-Larson and Menna, "this process includes direct and indirect teaching of Arab cultural values and practices through, for example, family stories, food, music, and holiday celebrations" (34). The researchers explain that ethnic identity develops over time and it "comprises a person's overall cultural identity" (35). What is important in this article is the claim that "self-exploration" might lead to the formation of ethnic identity in Arab American communities. This exploration is related to the context, in which ethnic identity "may be renegotiated repeatedly both in the public... and private spheres (e.g. family) of the everyday life of Arab youth" (35). 
Additionally, the researchers claim that what influences Arab Americans' acculturation to the American society are the country of origin and religion, the age, economic and sociopolitical reasons, the immigrants' gender, length of residence in the USA, and the fluency of English $(37,38)$.

The researchers highlight the role of family in the enculturation of their children. The families "provide the first and most immediate social context for the socialization of language, behavior, and cultural values. That context is often rich in the heritage or ethnic group culture(s)...immigrants are repeatedly challenged to reformulate their ethnic identities under a diversity of everyday social contexts and circumstances" (40). The researchers point out that there might be a conflict between acculturation to American culture, such as dating someone, and the enculturation to the Arab culture, such as arranged marriage rules (40).

Peek studies the development of Arab Americans' religious identity, in which the researcher finds out that formation of religious identity for Arab Americans is "a dynamic and ongoing process" (236). Additionally, the researcher notes that the development of religious identity "involves heightened reflection and self-awareness, individual choices, and the acknowledgment of others" (236).

Nobles and Sciarra claim that the cultural difference between Americans and Arab Americans must be taken into account when dealing with mental health issues of Arab Americans: "[Arab Americans'] political history, strong religious background, and significant differences with the dominant culture of the United States complicate issues of second culture acquisition for Arab Americans" (190).

In her article entitled "Parent Practices and Identity Outcomes in Arab Youth," Wrobel claims the formation of bicultural identity for Arab Americans youth is highly influenced by parenting practices, in which "authoritarian parenting practices typical collectivist in Arab cultures impact children differently than might be expected in Western societies. For adolescents and young adults experiencing cultural change, the nature of parents' acculturation, the degree of parental openness... all play a role in adjustment of youth as they experience cultural change" (2).

Furthermore, in his distinguished article entitled "Acculturation Process of Arab-Muslim Immigrants in the United States," Wekhian finds out that there are barriers that make Arab Americans' integration into the American society more complicated, such as "cultural and religious differences, distinctions in moral and ethical values, perception of gender relations, demonization of the Arab population in mass media, and discrimination are the major factors causing the overall struggles of the acculturation process" (96). The researcher claims that one of the obstacles of Arab Americans' acculturation to the American society is due to their fixed beliefs and insistence of preserving their Arab culture and living in their ethnic groups (96).

Based on the previous theoretical framework, the study attempts to investigate the ethnic identity crisis and the problem of acculturation and enculturation in Evelyn Shakir's "Let's Dance" focusing on how the lack of parental support and divorce, the American negative media stereotypes about Arabs, and the clash between Arab and American ethnic traditions can negatively influence the formation of ethnic identity and acculturation for Arab American teenagers.

\section{Ethnic Identity Crisis and Acculturation in Shakir's "Let's dance"}

In "Let's Dance," the protagonist Nadia has a slightly different conflict than the young women in Shakir's previous stories. Her mother, Dottie, is an American, and her father is an Arab. As Shakir notes, "Nadia's father was Arab, that was the point. A real Arab born overseas. Nabil had come to America to study, found a job, then sent for others in his family" (146). When her parents get divorced, Nadia feels doubly detached from both cultures. Nadia perceives that her problem lies in her linkage with the Arab ethnicity, which is stigmatized in America - even her mother calls her a "baby terrorist." Here, it should be stated that Nadia suffers from acculturation to her Arab ethnic identity because of the lack of enculturation about Arab culture from her family.

Moreover, after her divorce from Nabil, Dottie starts describing and mocking him as "boring...his dark eyes and thick black hair, even his dusky church, a form of false advertising. 'Bait and switch' a friend suggested" (147). Nadia does not like the image of her father in this way, so when her mother mocks of him and his physical appearance, she "had stormed off to her bedroom and slammed the door" (147). Nadia suffers from her parents' separation which psychologically influences her. However, Dottie's relationship with her husband's parents seems very fine, in which "she still kissed them on both cheeks, called them 'Mom' and 'Dad' wanted them to find her charming" (147). They are very kind with Dottie too; as the narrator reflects, "they didn't have it in them to be rude to this blond American whose English cavorted like a TV jingle" (147). They want their relationship to be kind with Dottie "for the sake of the little girl" (147). They also know the crisis of Nadia's ethnic identity which is due to the lack of support from her parents.

When Nadia's father moves to California, he becomes less of a presence in her life, and she feels cast adrift. Even when her grandparents go out of their way to make her feel at home, she still struggles to connect with their Lebanese language and traditions:

"Her jiddu, who'd been pacing downstairs all morning, would take her in his arms and kiss her head...Her sittu, soft to the touch and plump, would sit beside her on the sofa, smoothing back Nadia's straight, fine hair, laying her head on Nadia's shoulder, whispering in Arabic-'My heart, may you bury me.' Nadia's father translated. 'She's wishing you long life.' Her stepmother, not to be outdone, prepared a feast each evening. Rolled grape leaves one day, then stuffed eggplant in tomato sauce with pine nuts, then lamb with artichoke, and so on; for dessert, sticky pastries stuffed with white cheese, walnuts, or pistachios" (149). 
This warm welcome here is an attempt by her family to compensate Nadia for her loss of family ties and affection because of her parents' divorce and an indication to the importance of the concept of family, and the value of generosity in Arab culture and ethnicity. The description of food serves a double purpose here, in that it represents a linkage between the homeland and the family in America, and it is an effective way to teach Nadia the food traditions of her homeland. In other words, Nadia's grandparents try to acculturate her to her Arab culture to make her overcome her ethnic confusion and to make her more connected with her Arab ethnicity. Unlike Nadia, her grandparents who belong to the first or second generation immigrating to the USA do not suffer from the crisis of ethnic identity because they are more attached to their Arab culture.

Despite her grandparents' hard efforts, Nadia's meeting with her father when they walk the cliffs represents how their relationship is cold and not close: "he quizzed her on her schoolwork and on her mother's boyfriends, and, one year, on her teeth" (150). Nadia does not answer her father when he asks her; he addresses her in Arabic "Ya baba, sma'I minni" which means "You, my daughter, Take my advice," but she does not answer him because she does not know Arabic, the language of her ethnic group, "except for foods and for curses" (150). Knowing that his daughter does not know Arabic makes Nabil unhappy because he is more attached to his ethnic and cultural identities. We notice here how the protagonist is not adhered to her native culture and ethnicity through not knowing Arabic. In other words, she does not have a clear sense of belonging to her ethnic group. She is in between the American and Arab culture. When her father asks about her plan after graduation, she tells him "I'll do something. College, I guess" (150), but it is clear that she is confused.

As she grows up, Nadia does not develop a strong sense of belonging to her father's family, although she knows that they love her; she suffers from the crisis of constructing a hybrid identity because of the lack of enculturation to her Arab culture and traditions:

...those people in California were finally only characters in a book. When she looked back after going through security at the airport and saw her jiddu blowing his nose, her sittu in a flowered dress, hugging her black purse against her chest, the others to one side, their hands making little rubbings in the air that passed for goodbye waves, she threw a kiss, turned, and it was like closing the cover of the book and putting it away. (151)

The turning point in Nadia's life occurs when she befriends Nick, a student in her college history class. Because of her relationship with him, she starts to negotiate with both of her parents' assumptions about the sort of man who would be appropriate for her. As part of this negotiation process, Nadia becomes a self-actualized person - someone who becomes able to appreciate her Middle Eastern background and ethnicity within an American context.

Nadia first meets Nick when her teacher asks the students to introduce themselves, and Nick is embarrassed of his accent: "First, I ask please to forgive my accent...I am Greek...I hope to become a filmmaker" (153, 154), and his teacher encourages him by saying "Nonsense, your English is just fine" (153). Nick recognizes the difference between his native ethnic identity and the American, and the American negative stereotypes about his ethnicity. In other words, he seems more enculturated by his parents about that. Like her teacher, Nadia shows a positive reaction to Nick, which reveals her sympathy with him because she shares him her Middle Eastern ethnic identity: "He was unlike any boy she'd ever met. No one would call him handsome. His ears stuck out, a front tooth was crooked. But he was classy (her mother's word came to her out of nowhere), the way he held himself and smiled and moved his head. What smarter, richer world did he come out of? Nadia wanted to wrap one of his dark curls around her finger, she wanted to squeeze his slim hands with her own" $(153,154)$. She feels that there is a shared thread and a common ground between him and her, and for the first time, she introduces herself proudly. She says:

"I'm Arab." It was a sentence she'd never said before in her whole life. A spur-of-the- moment gift to Nick, a leap like a ballerina's - that's how she pictured it-lofting her to where he stood alone on the other side of an invisible hedge. Leaving behind that shadowy classroom of losers. Her desk was just behind his, and, as she spoke, he shifted around to face her. She smiled and inched her hands along her desk in his direction. She hoped he'd see that she was different" (154).

Thus, the protagonist here identifies herself with Arab ethnicity and culture because she wants to build a connection with Nick. Thus, it should be noticed here that Nadia is able to construct her Arab ethnic identity only when she befriends a boy belonging to her generation and age.

When Nadia tells Nick that the people in Cyprus and in America "say bad things about the Arabs" (155), he says that these people "are dumb" (155). He tells her that he tells the people in Cyprus that "Arabs and Cypriots are cousinseven our superstitions are the same-black birds, they predict death, the evil eye gives sickness to a child. Yes, we are very close" (155). In other words, Nick tries to build a bond between Arabs and Cypriots in which they belong to the Middle Eastern ethnicity and culture. It seems clear that both Nick and Nadia have the same feeling of ethnic identity. She seems aware of the American negative stereotypes about her Arab ethnic group.

The challenge for Nadia begins when Dottie criticizes Nick's religious belief and that he belongs to the same Orthodox church as Nabil's. Nadia opposes her mother's opinion by saying "Just because it didn't work out with you and Dad, doesn't mean I can never be friends with anyone in that religion” (156). This indicates that Nadia recognizes 
her parents' conflict which is the main reason behind her ethnic crisis. Yet Dottie tries to make Nadia dislike Nick based on her failed relationship with Nabil; she tries to depict Middle Eastern people as disrespecting women whether they are Christian Orthodox or Muslims: "You know they treat women terrible...Them, them. Your Orthodox. Almost bad as the Mohammedans"” (156). It is noted here that Dottie bases her thought on the American negative media depiction of Arabs.

Dottie's description of how Muslim men treat their women reveals how western feminists criticize the Eastern women subjugation and oppression by males: "Those Mooslims... They make the women dress like witches, all in black and cover up their arms and legs and half their faces" $(156,157)$. In other words, what Dottie is trying here to say is to equate all Middle Eastern people as one group who oppress their women. However, since Dottie's boyfriend is Jewish, she tries to defend the Jewish people and to say that "at least Jews have women rabbis" (157). Nadia becomes more detached and separated from her mother because of her inability to interact with her mother who belongs to another ethnic group.

When Nadia plans to visit her father's family with Nick, her mother tells her "Go, go. We'll just see what your father has to say" (159), a reference to her belief that Nabil will disapprove seeing his daughter travel with a man to whom she is not married. However, Nick realizes the culture of honor, and he knows that he should not exceed it in his relationship with Nadia. Nadia is also aware of her ethnic codes in her culture in terms of the relationship between a boy and a girl. She does not have sex with Nick except in her imagination: "she and Nick had never been to bed except in Nadia's imagination. And, she liked to think, in his. Until they met, she'd been what her girlfriends called 'a practicing virgin,' someone who'd tried sex once or twice and been in no hurry to go through that again" (159). Thus, sex was not on her agenda when she visits her family. What she wants to explore is her Arab ethnic and cultural identity to which she is supposed to be attached, but she does not feel it. Nick also has the same feeling; he wants to explore the shared thread that connects him with Nadia:

So it wasn't big-time sex on the agenda. But it was something. A point to be made, she sensed. But what? 'That I'm really Arab' was the best she could come up with. Nick would hear her grandparents' accents, their stories about the village, the homesickness in their voices. That edge of sadness had always hurt Nadia, as if it were a door closed in her face. But now it would weigh in her favor-like a credential on an application. Evidence that she and Nick, the immigrant boy, belonged together. That no girl in their class or in the school or that he might meet on the beach next summer could understand him so well (159).

Although it is clear that Nadia hopes to impress Nick with her father's family, she ends up negotiating a better and closer relationship with them, when she views them through a new lens.

Nadia's family reception for her and Nick starts with her grandparent's expression "Ahlan wa sahlan" (159) which means "Welcome, welcome to our house" (160) and their smiles. Her father shows them that he is not angry of Nick's coming, "but he'd acted as if his mind was elsewhere" (160). He wants his daughter to overcome her crisis. However, Nadia is angry because "in front of Nick, her father had made her take center stage and, of course, she'd come out sounding stupid" (160).

The description of Arab Lebanese traditional food prepared for Nadia and Nick reflects a tradition in the Arab culture in which the people show their guests their traditional food and customs. Here, we have a description of

"brown lentil soup with lemon, sole layered in a garlic and tahini sauce, salad of tender baby okra, andsomething even Dottie had never attempted-home-baked Syrian bread...Through the glass window, Nadia and Nick watched the loaves puff into pockets... Nadia remembered the time she'd accidentally knocked a piece of pita to the floor, how her grandmother had gasped and snatched it up and kissed it. She'd made Nadia kiss it too. After that, Nadia wondered if she had to do the same with plain old American bread. But nobody said, and she decided no" (160).

Thus, it is noted here that food serves as a reflection of her family's Arab traditions and ethnicity.

Nadia is still confused about her Arab ethnic identity, in which she wonders "Who's us?" when her father tells her about the invitation of a relative's wedding held in the Melkite church, in which he says "They do everything the same as us" (161). Although Nadia knows what her father means, she is still confused about her ethnic and cultural identity and her sense of belonging. In the wedding, Nadia and Nick "watched the exchange of rings-three times they were swapped between bride and groom. Her grandmother nudged her. Nadia saw she was holding up three fingers at her waist. 'Father, Son, Holy Spirit,' her grandmother whispered. She brought two fingers and a thumb together-as if reaching for a pinch of salt - and crossed herself' (162). We notice that the description of wedding ceremony is a constant theme in Arab American Young Adult literature, in which it is a way to depict how Arab Americans are linked to their native culture and traditions. 
Nadia does not like how the people dance in the wedding, "she could do a kind of disco but only if there were enough company on the floor for camouflage. She hated the way nondancers looked on, snapping fingers, whispering comments" (162). This means that Nadia is still confused about her sense of belonging to her traditions and culture.

The description of wedding ceremony and how the people dance represent the older generation's yearning to the traditions they have lost in America:

it wasn't that kind of wedding. It was old-country style, with dances that villagers in Lebanon had done for generations. Women took turns getting up to dance, alone or in pairs, their arms framing their faces or bent seductively behind their backs, their shoulders undulating like a river current. On the fringe of the dance floor, awkward prepubescent girls - her stepsister among them — were mimicking grown women and older sisters. Her father and his wife sat side by side, nodding at their daughter, calling out encouragement in Arabic, keeping time with their applause. Nadia saw that Nick was also clapping" (162). When Nadia is invited to dance with her stepmother and her grandfather, she tells them "I don't know how" (163). When her grandfather proposes to her to teach her how to dance, Nadia replies him "Not now, I can't" (164). Nadia feels confused in which she says "I will remember this moment all my life (164).

The description of the people's traditional dance reveals Nadia's confusion about her traditions, in which there is

"one man strumming on the oud, another drumming on a dirbakki, the third a showman on the tambourine. Soon half the room, it seemed, was on its feet, hands linked in a dance that wove between the tables like a snake. Bodies thrown forward, then head thrown back, then forward again, a kick, another step, and stamping on the floor. As it passed their table, Nadia's sister broke out of the line, took Nick by the hand and drew him from his chair, he went willingly, laughing and dragging Nadia with him. She tried to resist, but her hand was firmly in his grasp. She knew the steps, she'd seen them done a dozen times and, a little girl, had even practiced them at home. Nick watched the dancers' feet and soon caught on. Nadia kept her head down, afraid of making a mistake, wondering if she looked like she belonged" (164).

Thus, it is noted from the above quotation how Nadia is confused about assimilating to her people's ethnic traditions and about her belonging to her American culture; she keeps behaving as she is afraid from her people and from committing a mistake in front of them. Nick is more assimilated to her culture than her. He dances with the people without feeling embarrassed because he was acculturated by his parents.

Nadia's sense of confusion reaches its apex when she watches how "dancers in the rear struggled to keep up. Soon it changed pattern again, curling into a spiral. At the center, the leader broke free, beating a rapid tattoo with his heels, his arm raised over his head, twirling a handkerchief. An old woman stepped in, for a moment, to partner him, her hand to her mouth in a jubilant trill" (164). The description of her reaction to how the people dance reveals how she is excited and confused about her people's traditions and culture:

"Nadia stopped thinking, her mind no longer in charge of her limbs, her body on its own. As the musicians picked up the tempo, she felt sweat run down her back, the floor seemed to pulse under her feet. Faster and faster - people began falling out—Nadia held on, no turning back, no space for questioning. The room was a whirl, but she caught a glimpse of her jiddu, his arms lifted high in applause. She looked at Nick, who was looking at her, and they laughed. Wedged between tables, then slithering free, the line coiled again and embraced her. It was dancing her home" $(164,165)$.

Thus, from the above quotation it is clear that this dance represents Nadia's sense of ethnic identity and her belonging to her culture in which she firstly feels confused, but she tries to stay firm in the ceremony although the situation around her is weird to her; she observes her grandfather and Nick's dance as a way to get their emotional support to overcome her confusion and ethnic identity crisis until she feels that she is more attached to her people.

At the end of "Let's Dance," Nadia seems aware of her Arab ethnic identity and of her sense of belonging to her culture. When her mother receives her at the airport asking her about the visit, Nadia tells her "It was good" (165). This means that she feels comfortable now about her ethnic idenitity. When she shows her mom the photo her Jiddu (grandfather) gave it to her, she tells her mother "Mom, you can keep it. Jiddu said it's for you" (165). This means that the photo is a piece of evidence or an implied message to Dottie from Nadia's grandfather that Nadia now knows who she is, her identity, people, and ethnic traditions. The description of the photo depicts how Nadia integrates with her traditions, and how she feels connected with her Arab culture and ethnicity: "Dottie saw the back of a man's head and, over his shoulder, a circle of dancers. At first glance, she almost missed Nadia, slightly out of focus, her hair fallen over her eyes. But there she was, dancing in sync with her mates. Leaning back, lips parted, leg raised, a link in a chainunless you happened to love her, little to set her apart" (165). Thus, Dottie's first glance of the picture reveals how she doubts that her daughter will assimilate into her ethnic traditions, but in the second glance she views how Nadia reflects her sense of belonging to her ethnic identity. 


\section{Conclusion}

In the end, it is clear that the protagonist's ethnic identity crisis is due to many factors that made it more complicated. The lack of family support and the parental conflicts make Nadia unable to overcome this crisis. Additionally, Nadia's mother misconceptions about Arabs which are due to the American negative media stereotypes and the lack of her father's affection and support make her unable to overcome her confusion about building a hybrid ethnic identity at the beginning of the story, but because of her grandparents' support which is represented in socializing with Nadia and making her attend the traditional ceremony like the wedding, Nadia can have a clear sense of her Arab ethnic identity. Furthermore, the American negative media stereotypes about Arabs are one of the barriers that complicate the construction of ethnic identity for most Arab American young adults.

\section{References}

Awad, Germine. "The impact of acculturation and religious identification on perceived discrimination for Arab/Middle Eastern Americans." Cultural Diversity and Ethnic Minority Psychology 16.1 (Jan 2010): 59-67. Web. 22 Nov. 2016.

Britto, Pia Rebello, and Mona M. Amer. "An Exploration of Cultural Identity Patterns and the Family Context among Arab Muslim Young Adults in America." Applied Developmental Science 11.3 (2007): 137-50. Web. 23 Nov. 2016.

Hakim-Larson, J., and Menna, Rosanne. "Acculturation and Enculturation: Ethnic Idenity Socialization Processes" from: Handbook of Arab American Pyschology. London: Routledge, 2015. Web. 22 Nov. 2016.

Nobles, A., and Sciarra, D. "Cultural Determinants in the Treatment of Arab Americans: A Primer for Mainstream Therapists.' American Journal of Orthopsychiatry 70.2 (April 2000):182-191. Web. 20 Nov. 2016.

Peek, Lori. "Becoming Muslim: The Development of a Religious Idenitity." Sociology of Religion 66.3 (2005): 215242. Web. 22 Nov. 2016.

Semaan, Gaby. "Arab Americans: Stereotypes, Conflict, History, Cultural Identity and Post 9/11." Intercultural Communication Studies 2 (2014) : 17-32. Web. 23 Nov. 2016.

Shakir, Evelyn. "Let's dance."New York: Syracuse University Press, 2007.

Weaver, Kristin. "Arab Americans and Segmented Assimilation: Looking Beyond the Theory to the Reality in the Detroit Metro Area." Thesis. University of Oslo (Fall 2010): 1-135. Web. 12 Nov. 2016.

Wekhian, Jamil. "Acculturation Process of Arab-Muslim Immigrants in the United States." Asian Culture and History 8.1 (2016): 89-99. Web. 20 Oct. 2016.

Wrobel, Nancy. "Parent Practices and Identity Outcomes in Arab Youth." International Symposium on Arab Youth (May 29, 2013): 1-14. Web. 19 Nov. 2016. 